\title{
ENVIRONMENTAL STRAINS OF Cryptococcus neoformans VARIETY grubii IN THE CITY OF SANTOS, SP, BRAZIL
}

\begin{abstract}
SUMMARY
This study involved a total of 116 samples, 79 taken from pigeon droppings and 37 of atmospheric air taken close to accumulations of excrement. Cryptococcus neoformans var. grubii was isolated from 11 (13.9\%) of these samples. Other species of Cryptococcus were also isolated from these samples, such as C. albidus (12.6\%) and C. laurentii (8.9\%). C. neoformans was not isolated from the air samples, though $C$. albidus $(5.4 \%)$ was. All the strains of $C$. neoformans were found to belong to the A serotype $(C$. neoformans var. grubii). In regard to the studies with the antifungal agents 5-fluorocytosine, fluconazole, itraconazole, amphotericin $\mathrm{B}$ and voriconazole, by means of the microdilution method (EUCAST), we point out that one sample demonstrated resistance to fluconazole, this being especially significant because this is an environmental strain.
\end{abstract}

KEYWORDS: Cryptococcus neoformans; Pigeon droppings; Serotype; Antifungal agents.

\section{INTRODUCTION}

Cryptococcus neoformans is an encapsulated yeast whose teleomorphic state is a basidiomycete - Filobasidiella neoformans. It is a cosmopolitan fungus frequently isolated from soil rich in organic material, particularly pigeon droppings ${ }^{4,9}$. Nowadays, in respect to its morphological, biochemical, immunological and epidemiological characteristics, $C$. neoformans comprises three varieties: $C$. neoformans var. neoformans, C. neoformans var. gattii and C. neoformans var. grubii ${ }^{5}$.

Currently, the varieties of $C$. neoformans may be considered as belonging to five serotypes: serotype A (var. grubii), serotype D and $\mathrm{AD}$ (var. neoformans) and serotypes $\mathrm{B}$ and $\mathrm{C}$ (var. gattii $=\mathrm{C}$. bacillisporus $)^{3,15,25}$.

It has been observed that this yeast may be present in a wide range of locations such as old buildings, church towers, stables, basements, sheds and various open-air public places, all of which could become infective foci ${ }^{2,22,27}$.

C. neoformans can occur in low-frequency in the human species, as part of the transitory microbiota ${ }^{18}$. Despite its saprophytic existence, C. neoformans is able to infect and cause disease in immunocompetent hosts (serotypes B and C) and, mainly, in immunocompromised patients (serotypes $\mathrm{A}, \mathrm{D}$ and $\mathrm{AD})^{28}$. It can also infect other mammals, insects and birds ${ }^{6}$.
In Brazil, Cryptococcus infection continues to be a lethal disease related to Aids. One possible hypothesis can be the existence of phenotypes that are resistant to antifungal therapy. New antifungal agents have become available, resulting in a greater number of therapeutic options and a demand for "in vitro" susceptibility testing ${ }^{12}$.

The Antifungal Susceptibility Testing Subcommittee of the European Committee on Antibiotic Susceptibility Testing (AFSTEUCAST) has developed a proposed standard broth microdilution procedure for the determination of antifungal MICs of some species of yeasts. This standard is based on the M27-A2 broth microdilution reference procedure of the National Committee for Clinical Laboratory Standards (NCCLS). It incorporates some modifications to allow the automation of the susceptibility method and to permit the reduction of the incubation period ${ }^{11}$.

It is generally held that the disease cryptococcosis is acquired from the environment through the inhalation of yeasts and/or dried basidiospores with incipient encapsulation, depending on the immunological state of the host ${ }^{6}$.

It should be noted that the place studied here, Santos, is a city with beaches attracting countless tourists, and has a significant number of residents with Aids. The aim of this study was to verify the occurrence of $C$. neoformans and its varieties in samples taken from the environment, pigeon droppings and atmospheric air, determining the prevailing serotype and the susceptibility to antifungal agents. 


\section{MATERIALS AND METHODS}

City studied: The city of Santos is located on the coast of the state of São Paulo, $70 \mathrm{~km}$ from the city of São Paulo, and has a population of about 410,000. To the north it borders on the counties of Santo André, Mogi das Cruzes and Salesópolis; to the south, the Atlantic Ocean and Santo Amaro Island; to the east, the county of Bertioga; and to the west, the counties of Cubatão and São Vicente. The city comprises an island with an area of $39.4 \mathrm{~km}^{2}$ and a mainland area of $231.6 \mathrm{~km}^{2}$. Its altitude is two meters, being predominantly flat but circled by high hills. Its climate is tropical. Together with other counties, it is part of the low coastland area denominated as the Baixada Santista. It has served as a port city for a long time (since 1543), and at its center there are historical constructions and monuments along with many churches. As a coastal city, it contains a large number of beaches and gardens. In all of these areas there can be found hundreds of pigeons, in constant contact with the residents and tourists.

Environmental samples studied: The environmental samples were collected from church towers, old buildings and dockside warehouses, as well as streets downtown and along the beaches.

A total of 79 samples of pigeon droppings were collected along with 37 samples of atmospheric air taken close to areas with accumulations of excrement.

The pigeon excrement was collected in sterilized plastic bags, using spatulas and brushes, from various sites within the urban area of the city.

Air contamination was verified at 37 locations by way of plates exposed for 15 minutes.

Processing of the samples and yeast isolation: The samples were processed less than $48 \mathrm{~h}$ after collection. Approximately $2 \mathrm{~g}$ of each pigeon dropping sample was suspended in a flask containing $50 \mathrm{~mL}$ of saline solution supplemented with chloramphenicol $(0.1 \mathrm{~g} / \mathrm{L})$. After vigorous shaking for five min, the flask was allowed to rest for $30 \mathrm{~min}$ for phase separation.

A $2 \mathrm{~mL}$ volume of the supernatant was aspirated into test tubes for centrifuging. The sediment was serially diluted until $10^{-3}$, and the pure sample and its dilutions were cultured into Petri plates containing either Sabouraud dextrose agar (Difco) and niger agar (Guizotia abysinica) ${ }^{14}$, both supplemented with chloramphenicol $(0.1 \mathrm{~g} / \mathrm{L})$. The dishes were placed into an incubator at $30{ }^{\circ} \mathrm{C}$ and observed daily for 15 days.

Identification of isolated yeasts: Selection was made of colonies with a creamy white or creamy beige aspect grown in the Sabouraud dextrose agar (Difco) or of dark-brown or black colonies grown in the niger agar. These were examined by microscope for morphological analysis, stained by a solution of cotton lactophenol blue and nigrosine and transferred to tubes containing Sabouraud dextrose agar for isolation. After growing, the colonies were cultured into tubes containing niger agar for verification of the phenoloxidase activity, and into Christensen's urea agar $^{8}$. Positive samples were identified using a commercial yeast identification kit (API 20CAUX bioMéuriex). Culturing at $37^{\circ} \mathrm{C}$ onto Sabouraud dextrose agar and in a "mycosel" agar (Oxoid) were also carried out ${ }^{19}$.
Determination of the varieties isolated: The varieties of $C$. neoformans isolated were determined by culturing in CGB medium (L-canavanine, glycine and bromotimol blue) ${ }^{17}$. The control consisted of standard strains of $C$. neoformans serotype A (ICB 163) and $C$. neoformans serotype B (ICB 162).

Determination of serotypes: Serotyping of the C. neoformans isolates was carried out using the Crypto Check kit (Iatron Laboratories, Tokyo, Japan) with specific antisera. The standard strains were also used $^{18}$.

Assessment of the samples in regard to antifungal agents: Susceptibility tests were run using five antifungal agents (5fluorocytosine - 5FC, fluconazole - FZ, itraconazole - IZ, amphotericin $\mathrm{B}-\mathrm{AB}$, and voriconazole - VZ). The minimum inhibitory concentration (MIC) was determined according to the standard technique established by document M27-A2 ${ }^{24}$. These susceptibility tests included the standard sample of C. neoformans var. neoformans ATCC 90012.

The modifications include the use of RPMI 1640 supplemented with $2 \%$ glucose as the test medium, an inoculum size of $0.5 \times 10^{5}$ to $2.5 \times 10^{5} \mathrm{CFU} / \mathrm{ml}$, flat-bottomed trays, and spectrophotometric reading with a 50\% inhibition endpoint for azole agents and flucytosine and 90\% to azoles. In addition, a previous evaluation showed that MICs obtained by the EUCAST broth microdilution method are in close agreement with those obtained using the NCCLS reference procedure ${ }^{11}$.

Stock solutions were prepared in dimethyl sulfoxide, except flucytosine, and fluconazole which was dissolved in sterile distilled water. The assay medium was RPMI 1640 without sodium bicarbonate and with L-glutamine buffered to $\mathrm{pH} 7.0$ with $0.165 \mathrm{M}$ morpholinopropanesulfonic acid and supplemented with $18 \mathrm{~g}$ of glucose per liter to reach a final concentration of $2 \%$ (RPMI-2\% glucose; Oxoid S.A., Madrid, Spain $)^{10}$. Culture medium was prepared as a doublestrength solution and sterilized by filtration. Sterile plastic microtitration plates containing flat-bottomed wells were utilized (Corning Costar Europe, Badhoevedorp, The Netherlands). The plates contained $100 \mu \mathrm{L}$ of twofold serial dilutions of the antifungal drugs per well. Two drug-free medium wells for sterility and growth controls were employed. The final inoculum suspension contained between 0.5 $\times 10^{5}$ and $2.5 \times 10^{5} \mathrm{CFU} / \mathrm{mL}$, and an aliquot of $100 \mu \mathrm{L}$ was added to each well of the microdilution plate. The MIC endpoints (to inhibit the growth at $50 \%$ to azoles and $5 \mathrm{FC}$ and $90 \%$ to $\mathrm{AB}$ ) were determined after incubation at $30{ }^{\circ} \mathrm{C}$ for $72 \mathrm{~h}$ and analyzed according some breakpoints by NCCLS, 2002 or by some researches realized with drugs that have not these values standardized yet by this committee. We classified the strains in susceptible (S), susceptible-dose dependent (S-DD), intermediate (I) or resistant (R) without necessarily a correlation with clinical outcomes because for this are necessary studies of correlation "in vitro" and "in vivo". For FZ (S $\leq 8 \mu \mathrm{g} / \mathrm{mL} ; 8 \mu \mathrm{g} / \mathrm{mL}$ $>\mathrm{SDD}<16 \mu \mathrm{g} / \mathrm{mL} ; \mathrm{R} \geq 16 \mu \mathrm{g} / \mathrm{mL}) ; \mathrm{IZ}, \mathrm{VZ}(\mathrm{S} \leq 0.125 \mu \mathrm{g} / \mathrm{mL} ; 0.25 \mu \mathrm{g} /$ $\mathrm{mL} \geq \mathrm{SDD} \leq 0.5 \mu \mathrm{g} / \mathrm{mL} ; \mathrm{R} \geq 1 \mu \mathrm{g} / \mathrm{mL}), 5 \mathrm{FC}(\mathrm{S} \leq 4 \mu \mathrm{g} / \mathrm{mL} ; 8 \mu \mathrm{g} / \mathrm{mL} \geq$ $\mathrm{I} \leq 16 \mu \mathrm{g} / \mathrm{mL} ; \mathrm{R} \geq 32 \mu \mathrm{g} / \mathrm{mL})$; for $\mathrm{AB}(\mathrm{S}<2 \mu \mathrm{g} / \mathrm{mL} ; \mathrm{R} \geq 2 \mu \mathrm{g} / \mathrm{mL})$.

\section{RESULTS}

Of the 79 samples of pigeon droppings analyzed (Table 1), 11 (13.9\%) were positive for C. neoformans; 10 (12.6\%) samples were 


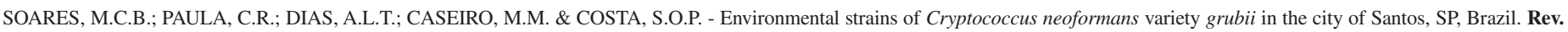
Inst. Med. trop. S. Paulo, 47(1):31-36, 2005.

Table 1

Yeast of the genus Cryptococcus isolated from environmental sources in the city of Santos, São Paulo state, Brazil

\begin{tabular}{|c|c|c|c|c|c|c|c|c|c|}
\hline \multirow{3}{*}{ Material } & \multicolumn{9}{|c|}{ Yeasts isolated } \\
\hline & \multicolumn{3}{|c|}{ C. neoformans } & \multicolumn{3}{|c|}{ C. albidus } & \multicolumn{3}{|c|}{ C. laurentii } \\
\hline & Pos. & Neg. & Total & Pos. & Neg. & Total & Pos. & Neg. & Total \\
\hline Excrement & 11 & 68 & 79 & 10 & 69 & 79 & 7 & 72 & 79 \\
\hline Atmospheric air & 0 & 37 & 37 & 2 & 35 & 37 & 0 & 37 & 7 \\
\hline Total & 11 & 105 & 116 & 12 & 104 & 116 & 7 & 109 & 116 \\
\hline
\end{tabular}

positive for $C$. albidus and $7(8.9 \%)$ samples were positive for $C$. laurentii.

Two samples of the total of 37 of atmospheric air were positive for C. albidus (5.4\%) (Table 1).

Of the 11 isolates of $C$. neoformans from pigeon excrement, four were from church towers and seven from other places (Table 2).

All of the isolates of $C$. neoformans were found to belong to serotype A (C. neoformans var. grubii).

In regard to susceptibility to the antifungal agents, one sample (sample 2) presented resistance "in vitro" (MIC equal to $64 \mu \mathrm{g} / \mathrm{mL}$ ) to

Table 2

Cryptococcus neoformans var. grubii isolated from pigeon excrement collected in different locations, in the city of Santos, state of São Paulo, Brazil

\begin{tabular}{lcc}
\hline Location & \multicolumn{2}{c}{ Sample number } \\
& Collected & Positive \\
\hline Church towers & 17 & $04(23.5 \%)$ \\
Old buildings & 15 & $00(0 \%)$ \\
Health institutions & 13 & $04(30.7 \%)$ \\
Educational institutions & 10 & $00(0 \%)$ \\
Dockside warehouses & 07 & $01(14.3 \%)$ \\
Open-air public places & 17 & $02(11.8 \%)$ \\
(downtown or beachside & & \\
public squares/streets) & & \\
\hline Total & 79 & $11(13.9 \%)$ \\
\hline
\end{tabular}

FZ. The results of the tests of susceptibility to antifungal agents are presented in Tables 3 and 4.

Fluconazole: The MIC values for FZ ranged from 0.12 to $64 \mu \mathrm{g} /$ $\mathrm{mL}$. Of the samples, $10(91 \%)$ were susceptible and one $(9 \%)$ was resistant.

Itraconazole: The MIC values for IZ ranged from 0.015 to $0.06 \mu \mathrm{g} /$ $\mathrm{mL}$. All the samples were susceptible to this drug.

Table 3

Determination of the minimum inhibitory concentration (MIC)* $(\mu \mathrm{g} / \mathrm{mL})$ of Cryptococcus neoformans samples isolated from pigeon excrement in the city of Santos, state of São Paulo, Brazil

\begin{tabular}{llllll}
\hline Sample & $5 \mathrm{FC}$ & $\mathrm{FZ}$ & $\mathrm{IZ}$ & $\mathrm{VZ}$ & $\mathrm{AB}$ \\
\hline 1 & 0.5 & 2 & 0.015 & 0.015 & 1 \\
2 & 16 & $64^{*}$ & 0.06 & 0.06 & 1 \\
3 & 8 & 2 & 0.015 & 0.06 & 0.5 \\
4 & 4 & 0.25 & 0.015 & 0.03 & 0.5 \\
5 & 2 & 2 & 0.03 & 0.12 & 1 \\
6 & 4 & 1 & 0.015 & 0.015 & 0.5 \\
7 & 1 & 8 & 0.03 & 0.25 & 0.25 \\
8 & 2 & 0.12 & 0.015 & 0.03 & 0.5 \\
9 & 2 & 0.5 & 0.015 & 0.03 & 0.5 \\
10 & 8 & 0.5 & 0.015 & 0.06 & 0.5 \\
11 & 2 & 0.25 & 0.015 & 0.03 & 0.25 \\
\hline
\end{tabular}

* resistant strain according to NCCLS, 2002; 5-FC $=5$-flucytosine; $\mathrm{FZ}=$ fluconazole; $\mathrm{IZ}=$ itraconazole; $\mathrm{VZ}=$ voriconazole; $\mathrm{AB}=$ amphotericin $\mathrm{B}$

Table 4

Evaluation of the range MIC and the susceptibility profile of the isolates

\begin{tabular}{|c|c|c|c|c|c|c|}
\hline \multirow[t]{2}{*}{ Drug } & \multirow[t]{2}{*}{ Isolate number } & \multirow{2}{*}{$\begin{array}{c}\text { Range MIC } \\
(\mu \mathrm{g} / \mathrm{mL})\end{array}$} & \multicolumn{4}{|c|}{ Susceptibility profile (\%) } \\
\hline & & & $\mathrm{S}^{\mathrm{a}}$ & $\mathrm{SDD}^{\mathrm{b}}$ & $\mathrm{I}^{\mathrm{c}}$ & $\mathrm{R}^{\mathrm{d}}$ \\
\hline FZ & 11 & $0.12-64$ & 91 & - & - & 9 \\
\hline IZ & 11 & $0.015-0.06$ & 100 & - & - & - \\
\hline $\mathrm{VZ}$ & 11 & $0.015-0.25$ & 91 & 9 & - & - \\
\hline $5 \mathrm{FC}$ & 11 & $0.5-16$ & 73 & - & 18 & 9 \\
\hline $\mathrm{AB}$ & 11 & $0.25-1$ & 100 & - & - & - \\
\hline
\end{tabular}

a: susceptible; b: susceptible-dose dependent; c:intermediate; d: resistant 
Voriconazole: The MIC values for $\mathrm{VZ}$ ranged from 0.015 to 0.25 $\mu \mathrm{g} / \mathrm{mL}$. Ten $(91 \%)$ of the samples were susceptible and one $(9 \%)$ presented a susceptibility dependent on dose.

5-Flucytosine: The MIC values for 5FC ranged from 0.5 to $16 \mu \mathrm{g} /$ $\mathrm{mL}$. Eight $(73 \%)$ of the samples were susceptible, two (18\%) were intermediate and one (9\%) presented a susceptibility dependent on dose.

Amphotericin B: The MIC values for $\mathrm{AB}$ ranged from 0.25 to 1.0 $\mu \mathrm{g} / \mathrm{mL}$. All of the samples were susceptible to this antifungal agent.

The results were interpreted according to document M $27 \mathrm{~A} 2^{24}$.

\section{DISCUSSION}

In a study carried out in 1994 in Mexico City, 251 samples of pigeon excrement were analyzed and $C$. neoformans was isolated in $52(20.7 \%)$. The greatest frequency of the isolation of this yeast was from samples collected from public buildings (31.2\%), followed by churches $(22 \%)$ and residences $(13.3 \%)^{7}$. In another evaluation, 522 samples of pigeon excrement collected from 14 cities in Puerto Rico were analyzed, of which 129 (24.7\%) were positive for C. neoformans, all of the isolates belonging to the variety neoformans ${ }^{29}$.

Some researchers carried out a study on 634 samples of pigeon excrement collected in Turkey, in 1998, wherein C. neoformans was isolated from only 29 (4.6\%) of the samples. Most of the isolates were obtained from samples collected from rooftops and pigeon nests ${ }^{32}$.

In the city of Rio de Janeiro, in 1993, 83 samples were studied from the soil and $13.2 \%$ of them were positive for C. neoformans ${ }^{21}$.

In a study carried out in the city of São Paulo, it was encountered positivity for this fungus in $21 \%$ of the places sampled from pigeon droppings ${ }^{23}$, while in the city of Rio de Janeiro, it was found a positivity of $31 \%$ in church towers with accumulation of pigeon excrement ${ }^{2}$.

The present study found positivity for C. neoformans in $13.9 \%$ of the samples of pigeon droppings from church towers, old buildings and open-air public places such as squares/parks and streets either downtown or at the beachside.

The method used in the present study was the same as that used by other authors ${ }^{2,23}$ and was unlike that used by others ${ }^{21}$ where samples were taken only from the soil with pigeon excrements.

It is likely that the low rate of isolation of the fungus in the current study is due to the low quantity of pigeon excrement available and the high temperatures in the city of Santos during the summer, as well as in other seasons. Cryptococcus does not grow at temperatures above $40{ }^{\circ} \mathrm{C}$ and the excrement is moreover subject to leaching as well as exposure to direct sunlight which can sterilize the sites contaminated by this yeast ${ }^{16}$. The saprophytic sources of $C$. neoformans have been researched in various parts of the world, but many questions concerning the ecology of the fungus and the epidemiology of cryptococcosis remain unresolved. In nature, excrement from pigeons and other birds, as well as from soils contaminated by these materials, represents the most significant source of $C$. neoformans var. neoformans, while $C$. neoformans var. gattii has been isolated from vegetal fragments of trees in some cryptococcosis-endemic areas ${ }^{13,20,30}$. In Brazil, both varieties of the fungus are recognized as etiological agents of cryptococosis $^{28}$.

The incidence of cryptococcosis has shown marked increases over the last years. The number of reported cases of cryptococcosis has risen to relatively high levels, and is considered the most frequent systemic infection of opportunistic fungus in patients with Aids ${ }^{14}$. Official data indicate that cryptococcosis occurs in $7 \%$ to $8 \%$ of the patients with Aids in the United States, Europe and South America and in up to $35 \%$ of these patients in Africa. In Brazil it occurs in around $12 \%$ of these patients, with high rates of morbidity and mortality $^{26}$.

It was reported a 54\% isolation rate for $C$. neoformans from dust taken from houses occupied by Aids patients ${ }^{31}$.

One hundred and fifty four human residences were analyzed, collecting 824 samples of dust from inside the houses and from the soil and from bird excrement outside the houses. C. neoformans var. grubii was isolated from 20 (13\%) of the residences; more specifically, from five of the 32 residences of Aids patients associated with cryptococcosis, four $(8.9 \%)$ of the 45 residences of Aids patients not associated with cryptococcosis, and $11(14.3 \%)$ of the 77 residences of apparently healthy individuals. The authors found that the main factor associated with household contamination by $C$. neoformans was the presence of birds either within the house or in its environments ${ }^{27}$.

In Brazil, serotype A (C. neoformans var. grubii) is the prevailing serotype found in environmental sources, such as pigeon excrement, vegetable remains and atmospheric air, followed by serotype $\mathrm{B}^{25}$.

In the current study the 11 isolates belonged to serotype A, in agreement with the literature review carried out by some authors concerning the Brazilian isolates of $C$. neoformans ${ }^{25}$. This same serotype $\mathrm{A}$ is also the most frequent in Brazilian clinical isolates (95\%), followed by serotype B (18.2\%) as reported in the above-mentioned review.

The samples were analyzed in respect to their susceptibility profile in regard to the five antifungal agents by way of the microdilution method. One strain was resistant to fluconazole, revealing a primary resistance to this drug; this finding is especially significant as this isolate was from an environmental sample. Other studies involving strains taken from the environment have warned about the resistance to this azolic derivative that is often used in the treatment of cryptococcal meningitis ${ }^{2}$. In respect to the other antifungal agents, all of the samples were either susceptible (IZ and $\mathrm{AB}$ ) or presented dosedependent susceptibility (VZ and 5FC).

So, this study has demonstrated that antifungal susceptibility results obtained by using the EUCAST proposed standard reference procedure are in close agreement with those achieved by the NCCLS M27A2 procedure. A great advantage of EUCAST standard is the reduction of the incubation time needed to determine the MIC (from $72 \mathrm{~h}$ to $48 \mathrm{~h}$ and 48 to $24 \mathrm{~h}$ ) and by this way, it may be more predictive of "in vivo" outcome for isolates that give unclear visual endpoints at a longer 
incubation time due to trailing growth. It is apparent that the trailing phenomenon can be an important potential source of inaccuracy in MIC determination in these cases ${ }^{1}$.

The results obtained provide a susceptibility profile of the environmental isolates, nevertheless additional studies in relation to the appropriate conditions for the realization of the tests and the establishment of clinical correlations should be undertaken.

These findings reinforce the hypothesis that pigeons droppings are an important factor of yeast infection in the urban environment, underscoring the importance of our study for a city with a high Aids rate, as is the case in Santos.

\section{RESUMO}

\section{Amostras ambientais de Cryptococcus neoformans var. grubii na cidade de Santos, SP, Brasil}

Analisaram-se 116 amostras, sendo 79 de fezes de pombos e 37 de ar atmosférico de regiões com acúmulo de fezes. Isolou-se Cryptococcus neoformans var. neoformans de 11 (13.9\%) destas amostras. Outras espécies de Cryptococcus também foram isoladas destas amostras tais como C. laurentii (8.9\%) e C. albidus (12.6\%), o qual também foi isolado de amostras do ar (5.4\%). Todas as amostras de C. neoformans foram sorotipo A (C. neoformans var. grubii). Em relação à avaliação do perfil de sensibilidade às drogas antifúngicas (5-fluorocitosina, fluconazol, itraconazol, anfotericina B e voriconazol) pelo método da microdiluição (EUCAST, 2002), destacou-se a presença de uma amostra com valor de concentração inibitória mínima (CIM) elevado para fluconazol, sendo de grande significância, uma vez tratarse de isolado ambiental.

\section{REFERENCES}

1. ARTHINGTON-SKAGGS, B.A.; LEE-YANG, W; CIBLAK, M.A. et al. - Comparison of visual and spectrophotometric methods of broth microdilution MIC end point determination and evaluation of a sterol quantitation method for "in vitro" susceptibility testing of fluconazole and itraconazole against trailing and nontrailing Candida isolates. Antimicrob. Agents Chemother., 46: 2477-2481, 2002.

2. BARONI, F.A. - Ocorrência de Cryptococcus neoformans em excretas de pombos localizados em torres de igrejas na cidade do Rio de Janeiro: fatores de virulência e sensibilidade aos antifúngicos. São Paulo, 2001. (Tese de Doutorado - Instituto de Ciências Biomédicas da Universidade de São Paulo).

3. BARRETO DE OLIVEIRA, M.T.; BOEKHOUT, T.; THEELEN, B. et al. - Cryptococcus neoformans shows a remarkable genotypic diversity in Brazil. J. clin. Microbiol., 42: 1356-1359, 2004.

4. BAUWENS, L.; SWINNE, D.; DE VROEY, C. \& DE MEURICHY, W. - Isolation of Cryptococcus neoformans var. neoformans in aviaries of Antuerp zoological gardens. Mykosen, 29: 291-294, 1986.

5. BOEKHOUT, T.; THEELEN, B.; DIAZ, M. et al. - Hybrid genotypes in the pathogenic yeast Cryptococcus neoformans. Microbiology, 147: 891-907, 2001.

6. CASADEVALL, A. \& PERFECT, J.R. - Cryptococcus neoformans. Washington, ASM Press, 1998.

7. CASTANÓN-OLIVARES, L.R. \& LÓPEZ-MARTÍNEZ, R. - Isolation of Cryptococcus neoformans from pigeon (Columbia livia) droppings in Mexico city. Mycoses, 37: 325-327, 1994.
8. CHRISTENSEN, W.B. - Urea decomposition as means of differentiating Proteus and Paracolon cultures from each other and from Salmonella and Shigella types. J. Bact., 52: 461-466, 1946.

9. CRISEO, S.N.; BOLIGNANO, M.S.; DE LEO, F. \& STAIB, F. - Evidence of canary droppings as an important reservoir of Cryptococcus neoformans. Zbl. Bakt., 282: 244-254, 1995

10. CUENCA-ESTRELLA, M.; DIAZ-GUERRA, T.M.; MELLADO, E. \& RODRIGUEZTUDELA, R.L. - Influence of glucose supplementation and inoculum size on growth kinetics and antifungal susceptibility testing of Candida spp. J. clin. Microbiol., 39: 525-532, 2001

11. CUENCA-ESTRELLA, M.; LEE-YANG, W.; CIBLAK, M.A. et al. - Comparative evaluation of NCCLS M27-A and EUCAST broth microdilution procedures for antifungal ausceptibility testing of Candida species. Antimicrob. Agents Chemother. 46: $3644-3647,2002$

12. DIAS, A.L.T.; MATSUMOTO, F.E.; MELHEM, M.S.C. et al. - Evaluation of broth microdilution method for susceptibility testing of Brazilian clinical and environmenta Cryptococcus neoformans isolates to five antifungal drugs. In: CONGRESS OF THE EUROPEAN CONFEDERATION OF MEDICAL MYCOLOGY, 9., Amsterdam, 2003. Trends in Medical Mycology, 123-125, 2003

13. ELLIS, D.H. \& PFEIFFER, T.J. - Natural habitat of Cryptococcus neoformans var. gattii. J. clin. Microbiol., 28: 1642-1644, 1990.

14. FERNANDES, O.F.L.; COSTA, T.R.; COSTA, M.R. et al. - Cryptococcus neoformans isolados de pacientes com Aids. Rev. Soc. bras. Med. trop., 33: 75-78, 2000

15. FRANZOT, S.P.; HAMDAN, J.S.; CURRIE, B.P. \& CASADEVALL, A. - Molecular epidemiology of Cryptococcus neoformans in Brazil and United States: evidence for both local genetic differences and a global clonal population structure. J. clin. Microbiol., 35: 2243-2251, 1997.

16. ISHAQ, C.M.; BULMER, G.S. \& FELTON, F.G - An evaluation of various environmental factors affecting the propagation of Cryptococcus neoformans. Mycopathologia (Den Haag), 35: 81-90, 1968.

17. KWON-CHUNG, K.J.; POLACHEK, I. \& BENNETT, J.E. - Improved diagnostic medium for separation of Cryptococcus neoformans var. neoformans (serotypes A and D) and Cryptococcus neoformans var. gattii (serotypes B and C). J. clin. Microbiol. 15: $535-537,1982$

18. LACAZ, C.S.; PORTO, E.; MARTINS, J.E.C.; HEINS-VACCARI, E.M. \& MELO, N.T. - Tratado de Micologia médica. São Paulo, Sarvier, 2002.

19. LARONE, D.H. - Medically important fungi: a guide to identification. 3. ed Washington, ASM Press, 1995

20. LAZERA, M.S.; CAVALCANTE, M.A.; TRILLES, L.; NISHIKAWA, M.M. \& WANKE, B. - Cryptococcus neoformans var. gattii: evidence for a natural habitat related to decaying wood in a pottery tree hollow. Med. Mycol., 36: 119-122, 1998.

21. LAZERA, M.S.; WANKE, B. \& NISHIKAWA, M.M. - Isolation of both varieties of Cryptococcus neoformans from saprophytic sources in the city of Rio de Janeiro, Brazil. J. med. vet. Mycol., 31: 449-454, 1993.

22. LEVITZ, S.M. - The ecology of Cryptococcus neoformans and epidemiology of cryptococcosis. Rev. infect. Dis., 13: 1163-1169, 1991

23. MONTENEGRO, H. \& PAULA, C.R. - Environmental isolation of Cryptococcus neoformans var. gattii and Cryptococcus neoformans var. neoformans in the city of São Paulo, Brazil. Med. Mycol., 38: 385-390, 2000.

24. NATIONAL COMMITTEE FOR CLINICAL LABORATORY STANDARDS (NCCLS) - Reference method for broth dilution antifungal susceptibility testing of yeasts. Approved Standard. 2. ed. Wayne, 2002. (Document M 27 A2. vol. 22, No. 15). 
SOARES, M.C.B.; PAULA, C.R.; DIAS, A.L.T.; CASEIRO, M.M. \& COSTA, S.O.P. - Environmental strains of Cryptococcus neoformans variety grubii in the city of Santos, SP, Brazil. Rev. Inst. Med. trop. S. Paulo, 47(1):31-36, 2005.

25. NISHIKAWA, M.M.; LAZERA, M.S.; BARBOSA, G.G. et al. - Serotyping of 467 Cryptococcus neoformans isolates from clinical and environmental sources in Brazil: analysis of host and regional patterns. J. clin. Microbiol., 41: 73-77, 2003.

26. PAPPALARDO, M.C.S.N. \& MELHEM, M.S.C. - Cryptococcosis: a review of the Brazilian experience for the disease. Rev. Inst. Med. trop. S. Paulo, 45: 299-305, 2003.

27. PASSONI, L.F.C.; WANKE, B.; NISHIKAWA, M.M. \& LAZERA, M.S. - Cryptococcus neoformans isolated from human dwellings in Rio de Janeiro, Brazil: an analysis of the domestic environment of Aids patients with and without cryptococcosis. Med. Mycol., 36: 305-311, 1998.

28. ROZENBAUM, R.; GONÇALVES, A.J.R.; WANKE, B. et al. - Cryptococcus neoformans varieties as agents of cryptococcosis in Brazil. Mycopathologia (Den Haag), 119: 133-136, 1992
29. RUIZ, A.; VÉLEZ, D. \& FROMTLING, R.A. - Isolation of saprophytic Cryptococcus neoformans from Puerto Rico: distribution and variety. Mycopathology (Den Haag), 106: $167-170,1989$.

30. SORRELL, T.C. \& ELLIS, D.H. - Ecology of Cryptococcus neoformans. Rev. iberoamer. Micol., 14: 42-43, 1997.

31. SWINNE, D.; DEPPNER, M.; MANIRATUNGA, S. - Aids-associated cryptococcosis in Bujumbura, Burundi: an epidemiological study. J. med. vet. Mycol., 29: 25-30, 1991

32. YILDIRAN, S.T.; SARACLI, M.A.; GÖNLÜN, A. \& GÜN, H. - Isolation of Cryptococcus neoformans var. neoformans from pigeon droppings collected throughout Turkey. Med. Mycol., 36: 391-394, 1998.

Received: 8 July 2004

Accepted: 16 November 2004 